\title{
Revisiting the Chinese Room: Looking for Agency in a World Packed with Archaeological Things
}

\author{
Artur Ribeiro
}

\begin{abstract}
Posthumanist approaches in archaeology have given plenty of focus to things in the last decade. This focus on things is a reaction to the over-anthropocentric view of social life advanced by postprocessual archaeologists. Whereas agency of more than 10 years ago was about how individuals expressed purpose and identity, agency today is about how both humans and non-human objects affect one another in a symmetrical manner. It seems without doubt that Posthumanism has contributed greatly to new understandings of social reality, but in the process it has also forced archaeologists to sacrifice many topics of interest, namely those involving consciousness and purpose. But is this sacrifice really necessary? This is one of the central problems of Posthumanism: it disallows a compromise of ideas from more conventional social theory (e.g. norms, purpose, practice) with those of posthumanist theory. This paper revisits John Searle's 'Chinese Room' and reiterates what this thought-experiment meant to understanding consciousness and purpose. The thought-experiment highlighted the differences between humans and machines and demonstrated that, even if a machine could replicate human purpose, it would still not be considered human because, unlike mechanical processes, human purpose is based on ethics. The thought-experiment was the first step in debunking the computational theory of mind. In light of this thoughtexperiment, the paper argues that, in a world where things interact with humans, we should think of agency in terms of ethics and keep the focus on humans.
\end{abstract}

\section{Philosophical thought moves on}

Philosophy has been a large part of archaeology since the early heydays of processual archaeology, and it is in current times that philosophy seems to have had its greatest impact in our discipline. This is especially true of posthumanist approaches in archaeology, which have borrowed many ideas from philosophy such as those of Martin Heidegger (e.g. Olsen 2010), Bruno Latour, who prefers to be identified as a sociologist of scientific knowledge (e.g. Webmoor \& Witmore 2008), Graham Harman (e.g. Pétursdóttir 2017) and Gilles Deleuze (e.g. Harris 2014) to name only some of the more prominent ones. ${ }^{1}$

Despite its strong presence, it also seems fair to say that only a very small proportion of current philosophy is being incorporated in archaeology. There is, for instance, a surprising lack of language philosophy, philosophy of economics, AngloAmerican metaphysics, naturalism (although evolutionary and cognitive archaeology can be considered derived from naturalist philosophy), ethics and morality, and philosophy of society. I do not mean to reprimand archaeology for this absence-it is of course not easy for archaeologists, who have spent years, perhaps even decades, studying the intricacies of archaeological practice, to go that extra mile and familiarize themselves with every philosophical topic available. But this absence can be problematic at times-it can mislead certain scholars into believing that current philosophical trends in archaeology are actually representative of the state-of-the-art

Cambridge Archaeological Journal 31:3, 533-541 @ The Author(s), 2021. Published by Cambridge University Press on behalf of the McDonald Institute for Archaeological Research. This is an Open Access article, distributed under the terms of the Creative Commons Attribution licence (http:// creativecommons.org/licenses/by/4.0/), which permits unrestricted re-use, distribution, and reproduction in any medium, provided the original work is properly cited. 
outside it. Naturally, the absence of a large part of philosophy is due to obvious reasons-lack of time, lack of funding and lack of interest-however, besides these obvious reasons, posthumanist archaeologists have also been aggressively vetting alternative philosophical ideas, often through uncritical hand-waving. In very general terms, this vetting has involved the dismissal of asymmetrical conceptions of humans (e.g. Witmore 2007, 548), the dismissal of dualistic conceptions of reality (e.g. Harris \& Cipolla 2017, 31) and the dismissal of interpreting subjects (e.g. Jones et al. 2013; Olsen 2012).

The main problem stemming from this dismissive attitude is an over-simplified perception of what posthuman philosophy actually entails, what benefits archaeology can gain from it and what posthuman philosophy actually represents beyond archaeology. For example, despite the heavy critique of dualisms and subjectivism ${ }^{2}$ by posthumanists, it is important to recognize that outside archaeology, dualists and/or subjectivists have not folded (e.g. Pippin 2005; Sorell 2005), and naturally, in archaeology they should not fold either. Furthermore, not all philosophical schools have been covered by posthumanist critique: philosophers have not been idle since the emergence of posthumanist theory; there are countless new ideas and trends in philosophy today. In fact, the posthuman critique we keep hearing about in archaeology (e.g. Braidotti 2013) is already somewhat outdated, with some pioneering philosophers already presenting very compelling and widespread philosophical critiques of Posthumanism itself (e.g. Meillassoux 2008; Žižek 2014).

From an archaeological perspective it would seem that the posthumanisms are the most popular intellectual trend at this very moment, but this could not be further from the truth. For example, if we were to enter any large academic bookstore and search for academic manuals on metaphysics, we would probably find Loux and Zimmermann's Oxford Handbook of Metaphysics (2003), Loux and Crisp's Metaphysics - A contemporary introduction (2017), Van Inwagen's Metaphysics (2014) and probably Kim, Sosa and Rosenkrantz's A Companion to Metaphysics (2009) - now, a brief perusal of these books (some of them around 700 pages long) reveals that not a single one refers to the writing on metaphysical ontologies by posthumanists. Once we step outside the bubble of archaeological theory, an obvious disjuncture becomes evident: posthumanist theory is just one of many perspectives, despite claims of its widespread acceptance by archaeological theorists (Olsen et al. 2012).
In light of this state of affairs, it bears reminding that philosophy has come up with alternative ways (or strengthened previous ways) of thinking about human action and societies, and the aim of this paper is to present some of these alternatives. In particular, it aims to describe how philosophy of society of recent years has emerged as the study of ethics, and what this means to our archaeological interpretations.

\section{'Stop right there, assemblage! You are under arrest!'}

Posthumanists want an archaeology packed with material things, regardless of whether this is of interest to archaeologists, whether it answers the research questions in need, or whether the methods suggested by posthumanists are adequate. Things, things, things! It is all about the things! Given that the world is packed with things, any description of social life without things would have to be considered inadequate. Social life is built on things! Mobile phones, gifts, love letters, etc., and without these things, social life would not be possible. Thus, the prime approaches promoted by posthumanists are those that emphasize flat or symmetrical relationships between human and non-human things, and to a certain extent, things-in-themselves, and thus, they have turned to actor-network theory (Latour 1999), assemblage theory (DeLanda 2006) and Object-Oriented Ontology (Harman 2017).

But one of the stranger aspects about these posthuman approaches, at least from my viewpoint, is the jarring disconnect between the picture of social life painted by these approaches and the actual picture witnessed in everyday life. Thus, one of the common themes among posthuman theory is the idea of distributed responsibility among different actants or ontological types within a network (Bennett 2010a, 28; Latour 1999, 177), yet in everyday life, regardless of the network of actants, our practices still give primacy to human responsibility. For instance, no one would deny that writing a book requires an assemblage of objects, yet even the most radical posthumanists identify themselves as authors of their books and papers. Why are laptops, printers, binders, proofreaders, copy editors, etc., not considered authors of publications? We can write a million articles saying how humans are not the centre of the universe, but this argument falls apart when we turn on the internet, read one of Trump's inane tweets and blame him, Donald Trump, for the problems he is causing in America and the world. Why do we not blame the Chinese factory worker who produced the phone on which Trump is tweeting? Why do 
we not blame the phone itself? And let us imagine that yes, responsibility should be spread out across the network/assemblage, which contains Trump, the phone and the Chinese factory worker, and everything else-if Trump were to commit a crime, say treason, through that phone, should the impeachment process be conducted for the whole network/ assemblage? Should there be a prison for objects, such as phones? Why, or why not?

At no point does admitting that there is some ethical 'asymmetry' when it comes to human and things deny the capacity of objects to act or to affect. We have all heard the countless examples of the affordances of objects (Knappett 2004), such as how the washing machine liberated women from the menial task of having to wash clothes by hand, expressed brilliantly in Hans Rosling's famous TED Talk (https:// www.youtube.com/watch?v=BZoKfap $4 \mathrm{~g} 4 \mathrm{w}$ ). There is also, of course, considerable literature on the affective entanglement of human, animals and things (Hamilakis 2017; Harris 2014). The point is, regardless of the role of objects in social life, humans, especially those living in western liberal economies, still tend to assign responsibility to other humans. When confronted with this, posthumanists, rather than trying to figure out why responsibility operates in this manner, simply dismiss this as the wrong way of being (Bennett 2010a; Braidotti 2013; Latour 1993; 1999).

For instance, Jane Bennett has highlighted the case of the 2003 blackout that affected 50 million Americans (2010a, 24ff), which could not be pinned down to a single cause or reason (e.g. human error or a single environmental factor, such as a hurricane), and she used this example in support of a relational metaphysical ontology of vibrant matter, similar to Bergson's Elan vitál and Hans Driesch's Entelechy (Bennett 2010b), an ontology that sees responsibility as distributed across a 'confederation' of human and non-human things (Bennett 2010a). But is this not a rather over-radical way of recognizing the issue of responsibility? Responsibility, and all the institutions that handle responsibility in contemporary society, were created with the aim of tackling justice; they were not conceived as ontologies. Thus, modern legal institutions do not base their legislative systems on ontological principles that claim all and only humans have responsibility, or that they have responsibility at all times and places, which is why we see these same institutions shift responsibility around, or even deny the notion of responsibility altogether. For instance, the Eyjafjallajökull eruption in Iceland in 2010 created an ash cloud that stranded millions of travellers on both sides of the Atlantic. In this situation, travel-insurance companies refused to pay the millions lost in travel costs, stating that this event was the result of an 'act of God'. The expression 'act of God' is a de facto legal definition (Garner 1999), referring to events outside human control, such as tornadoes and tsunamis. Granted, the travel-insurance companies acted out of selfishness, yet nevertheless they appealed to de facto legal concepts that allowed them to dismiss human accountability, proving that they operate on the distinction between events caused by humans and those which are not.

The central problem in Bennett's object agency can be understood through an idea that is familiar to archaeologists: not recognizing historical particularism. In her support of a posthuman understanding of agency, Bennett has ignored specific historical, social and political contexts where differential access to power, traditions and legislation will all affect how responsibility is interpreted. Just because there are several cases where responsibility cannot be traced to humans, it does not mean that all events in history happened independently of informed choices made by humans. Instead of the 2003 blackout, how would the 2018 \#metoo movement react to the argument that responsibility cannot be tracked to specific individuals, Harvey Weinstein, for instance? Or that, as elements within the networks of rape and assault, the victims are as much agents (actants) as their predators?

To the posthumanists who believe I have gone too far with this argument, that I have oversimplified, misunderstood and distorted posthumanist credo-I would retort that it was posthumanists who started this practice in the first place: any theory or idea that somehow focuses on humans can and should be oversimplified, misunderstood, distorted $^{3}$ - and ultimately rejected. For the posthumanists, any work published today that still embraces subjectivism or normativism is all the same: anthropocentric and therefore expendable. If these scholars do not subscribe to posthumanist dogma, then away with them (Ribeiro 2019)! With Posthumanism, what we end up with is depleted theories: ideas and arguments so scared to commit to the uniqueness of human history that they end up being just generic platitudes about reality. For example, Oliver Harris describes assemblages as not only containing things and humans, but also emotions (2017, 129), rules, laws, and behaviours (2018). It seems hardly debatable that societies do, in fact, contain all these elements, but in what capacity, for what purpose, and through which causal mechanisms do they all manifest in an assemblage? Let us apply Stephen Turner's pertinent question 
(1994) to assemblage theory: how does a norm suddenly appear in a society? Does it come from a human mind? From social interaction? From causal chains? Does it 'emerge' magically out of nothing? ${ }^{4}$ It is precisely these questions that posthumanists have disallowed us to answer.

From an ontological standpoint, perhaps Harris is in fact accurate in stating that reality is composed of assemblages, which contain things, humans, emotions, and rules, but the ontology in itself cannot explain why and how all those elements come into existence, except in very broad and generic terms. The issue at hand is not ontological, but methodological. In their crusade against anthropocentrism, dualisms and symbolism, the posthumanists have thrown away the baby with the bathwater-the methodologies that explain why most human actions are eminently ethical.

\section{Revisiting the Chinese Room}

It is precisely on the topic of ethics that groundbreaking ideas have been put forward in philosophy, especially through the revival of Hegelian philosophy in the work of Vincent Descombes (2001; 2014), Charles Taylor (1975; 2015), Slavoj Žižek (2012; 2014), Jean-François Kervégan (2018) and Robert Pippin $(1989 ;$ 2008; 2011). The first step to understanding Hegelian ethics is simple: no one is an agent unless one has ownership over an action (Pippin 2008, 8). To understand agency is to understand how different humans, in different periods and places, could claim ownership over actions. To put it in even more simple terms, recognizing agency is understanding the conditions that allows humans to claim 'we did this' or 'I did this'.

A thought-experiment might be useful to help us understand what this all means. In 1980, John Searle presented a very interesting idea with the aim of highlighting the logical contradictions of the computational theory of mind. This thoughtexperiment, called the Chinese Room was thoroughly criticized by Searle's contemporaries and remains to this day poorly received. Unbeknown to Searle at the time, the Chinese Room did something that very few scholars remark upon: it highlighted the difference between a mechanical action, one without any sort of ethical implication, and an intentional action, which falls within ethical purview. First, let us understand what the experiment consisted of.

Imagine that John Searle is in an empty room and he is given three batches of text written in Chinese and a set of instructions written in English.
John Searle knows no Chinese; in fact, he is barely able to differentiate Chinese from Japanese. Now the first Chinese text is called the 'Script', the second is called the 'Story' and the third is called 'Questions'; finally, the English instructions are called the 'Program'. Now, what the instructions in English provide is a way for Searle to correlate the different Chinese texts, and by correlate, it simply means that Searle can identify symbols by their shape and, through the English instructions, replace them with different symbols. With these instructions he correlates the 'Script' to the 'Story' and correlates the 'Questions' to these two previous texts, allowing him to produce a fourth text: 'Answers to the Questions'. Finally, imagine that with some practice John Searle becomes so good at following the English instructions that at one point, a person who understands Chinese will not be able to realize that the 'Answers to the Questions' are written by a nonnative Chinese speaker. From the perspective of someone outside the Chinese Room, it would seem that John Searle knows Chinese; however, what he is doing is simply following rules without actually understanding the purpose of the rules, nor the content of the Chinese texts. If Searle were to be handed texts in English, which he clearly understands, he would not need any instructions: he could just read the three English texts, the 'Script', the 'Story' and 'Questions', and produce 'Answers to the Questions' directly.

The point of this thought-experiment was to undermine several premises of the computational theory of mind, namely the idea that computer programs are similar to human understanding (Verstehen). As Searle concluded: 'as long as the program is defined in terms of computational operations on purely formally defined elements, what the example suggests is that these [The Program] by themselves have no interesting connection with understanding' (Searle 1980, 418, emphasis mine). I do realize that thought-experiments have their limitations (Dennett 1991, 440), but understood from a more casual perspective, the intuition desired by the Chinese Room is simple: it aims to separate those actions that are purely mechanical, that is, that simply follow blind instructions (such as those of the Chinese Room), and those actions that are intentional by the actor, those that Searle can claim are truly his. What is incredibly insightful about this thought-experiment was something that Searle did not really dwell upon: the ethical implications of his 'Answers to the Questions' in Chinese, which followed the 'Program' he was given, will of course be different from the implications of answers in English. 
In Chinese, Searle is acting as if in a master/slave situation, more specifically, as a slave following rules to something whose consequences he has no control over, whereas in English, Searle would give answers that are truly his own. This is what Hegel understood as the self-legislative character of norms (Pippin 2008, 17). To put it more simply, to understand English is to apply the rules of English in a way that allows Searle to express actions as his own (Pippin 2008, 36). To the question posed by Rosi Braidotti in her latest book $(2019,14)$, 'What happens when thinking, reasoning, assessing risk and opportunities are executed by algorithmicallydriven computational networks instead?', well, unless the computers hold ownership (and responsibility) over these actions, ownership that humans do not seem to want to relinquish, then ... nothing changes-not in a dualistic reality nor a relational or materialist one.

\section{With great responsibility, comes great power}

From the perspective of the posthumanist approaches in archaeology, there is no clear way as to how one could differentiate the fact that in one language (Chinese), Searle's answers cannot be said to be his, whereas in another language (English), we can. Before the posthumanists throw at me a million examples of how Searle's Chinese Room could be described through assemblage theory, or how your favourite posthumanist philosopher has talked about something similar in some obscure publication, the argument I am making is not that the Chinese Room cannot be described through posthumanist approaches; it is that its understanding cannot derive from a materialist and/or relational analysis. I have yet to see a way that one can explain the concept of human understanding, as exemplified by the Chinese Room, without having to employ nonmaterialist and non-relational theoretical principles.

Whereas both classic agency theorists (e.g. Anthony Giddens, Roy Bhaskar) and object agency theorists recognize agency as an ontological certainty, Hegel's rational agency assumes that no human is an agent unless that human lives within a social and historical context that allows the actions of the agent to be recognized as his or her own, or in other words, of their responsibility (Pippin 2008, 5). This does not mean framing human action according to our own moral norms (e.g. good and evil), but recognizing those cases where we can empirically observe and deduce that action comes from the agent (individual or collective). On a more practical level, this would mean an archaeology that studies what John Barrett (1988) and John Robb (2010) have respectively called fields of discourse and fields of action; the difference being that, rather than thinking of action in terms of either discourse or action, we must think of them in terms of ethics.

On a less abstract level, two crucial working concepts into research of ethics are 'freedom' and 'responsibility'. From Hegelian standpoint, what these two concepts necessitate is the following: the more freedom a given social system provides its members, the more responsibilities those same members accumulate. To return to the Chinese Room example, the freedom entailed by knowing a language involves being responsible for what you say in that language; in the case of Searle, his knowing English means he is responsible for what he says and writes in English, whereas when he is following directions to write in Chinese (i.e. The Program), he is exempt from responsibility of the content of what is written.

What does this mean in terms of archaeological interpretation? In Iberia, for instance, the transition from the Copper Age to the Bronze Age (c. 23002000 ВСE) entailed some radical restructuring of the social and ideological landscape (Lillios 2020), which must also have re-shaped the ethical framework of the societies living in this region. From an economic perspective, the trade networks that were established and consolidated during the Copper Age, which involved the trade of raw goods, some of prestige nature, gradually collapsed during the last centuries of the third millennium BCE. This gradual dissolution of the trade networks coincided with two different events: the $4.2 \mathrm{kyr}$ climatic event (Hinz et al. 2019) and the gradual arrival of newcomers, with Steppe ancestry, to the Iberian Peninsula (Olalde et al. 2019). In particular, the increase of Steppe ancestry in Iberia is interesting because it must forcefully have altered the kinship systems in play in Iberia (see, for instance, the wealth inequality induced by kinship systems in Lech Valley, Germany (Mittnik et al. 2019)). Now, as pointed out by Larry Siedentop (2014), very tight-knit kinship systems constrain the individual—or, to be more accurate, looser kinship systems allow more individual liberty. In tight-knit kinship systems, where exogamy is very tightly controlled, the freedom and consequent responsibility over sexual encounters and matrimony rights is in the hands of very few (e.g. social leaders like patriarchs/matriarchs), and it is these few who decide how much exogamy is allowed. In other words, these are the social members who write the 'Program' as to how others behave when it comes to sexual encounters and matrimony. In Iberia, and 
probably elsewhere in Europe during different stages, the introduction of Steppe ancestry was, above all, a change in local kinship systems, which in turn allowed for a different ethical framework to be established. To cite Roy Wagner,

When I speak of 'exogamy', I mean the moral injunction to select recognised sexual partner and/or spouses from social units other than those of which one is a member (or to which one is otherwise closely related). In all instances these injunctions are contingent upon the ideal moral codes of the cultures concerned. (Wagner 1972, 602, emphasis mine)

Naturally, the expansion of exogamous ties to allow Steppe ancestry relations in prehistoric Iberia is still a far cry from the sexual and matrimonial liberties one has in modern-day western economies, but it is nevertheless a step towards increased freedom and responsibility.

A completely different set of freedoms and responsibilities can also be witnessed in Roman times, when the practice of using magical curse tablets was in effect. Curse tablets are curses that are inscribed onto small objects, usually lead, and deposited in areas where the curse could reach underground deities (e.g. bodies of water, or buried underground next to temples). These curses were usually directed to other people, in order to affect them negatively. For instance, some curses were to silence people in juridical trials, to kill off competition in love triangles, or to reduce the number of family members when inheritance was to be divided. Unlike the more socially accepted religious practices, which were performed in public and relied on appeals to the standard deities of the Roman religious pantheon, curses were considered anti-social, were produced in private and relied on the help of chthonic deities.

When considering magical curse tablets from a social perspective, a key observation one must make is that magical practices only exist in opposition to religious practices. In a classic dialectical process, magic arose in classical Greece and was introduced into the Roman empire as a process of subverting religious practices, more specifically, by subverting Persian religion (Bremmer 1999). This, in a way, is a freedom gained by members of the Roman empirethat is to say, it was only in opposition to religious practice that magic could arise and could be practised. In fact, it was precisely the public and formal nature of conventional religious practices that led to the allure of magical practices-practices that, while anti-social, were nevertheless more direct and coercive than conventional religious practices (Versnel 1991a).
But what is most interesting about these magical curse tablets is their social contradictionthe production and performance of a curse tablet is anti-social, private, hidden, yet they hold considerably more social power than religious practices because it allowed the one who cursed to contact chthonic deities in a direct manner and coerce them to act on their behalf (Versnel 1991b). At face value, it might seem ironic that the 'freedom' to curse would entail heavy responsibilities upon those who performed the curse-but this is not irony at all; from a Hegelian standpoint this makes perfect sense, since freedom and responsibility work as a dialectic; one cannot have one without the other. To put it in other words, the curse tablets are the perfect example of objects that reflect the ethics of their time; they demonstrate that what is ethically correct behaviour is best understood when one highlights what is unethical. Additionally, as a practice that stood outside what was convention, it must be assumed that there was no peer pressure to produce magical curse tablets. This means that one had to intentionally choose to do so. To frame this according to Hegelian ethics: to look for a piece of lead, inscribe (or ask someone else to inscribe) it with a curse and surreptitiously place it within the ground or a body of water is to take ownership of the possible consequences resulting from those actions.

\section{Theory as critique, theory as construction}

Despite the limitations to posthumanist approaches I have pointed out above, they have proved to be excellent as far as methodologies go, namely those involving network analysis. But there is only so much these methodologies can tell us about past (and present) social contexts. Thus, I see a natural alliance between posthumanist methodologies and more 'traditional' theories that are based on normativism, subjectivism and rationalist ethics. At face value, it might seem that posthumanist and 'traditionalist' approaches cannot be combined, but that is not necessarily true. For instance, the work on inequality and the Anthropocene by Alf Hornborg (2019) demonstrates a masterful weaving of both actor-network theory and Marxist theory.

Ultimately, it seems quite evident that there cannot be a single monolithic theoretical programme that can cover all the explanatory potential provided by the past (Kristiansen 2004, 77). While some questions and interests can in fact be uncovered by posthumanist approaches, others simply cannot.

With this in mind, it makes sense not only for our attention to go beyond Posthumanism to the 
work developed by neo-Hegelians, but also to revisit those theories and approaches, such as practice theory (e.g. Bourdieu 1977; Giddens 1984), Marxist theory, and also anthropological theories that help us make the actions of agents understandable (e.g. Bell 1992; Helms 1998; Kopytoff 1986; Sahlins 1972). I share the exasperation felt by Andrew Gardner and Ethan Cochrane (2011): archaeology has to stop the practice of replacing one set of half-baked ideas for another set of half-baked ideas. It is high time to move forward in a more engaging manner.

\section{Notes}

1. As has often been repeated, posthuman approaches are not a single monolithic block of ideas. Nevertheless, I am addressing them here as a general trend, since what I discuss in this paper are their more common features. I do realize that many of the issues addressed here do not necessarily reflect upon all the sub-trends within Posthumanism, but due to constraints of space, I cannot address how each of my arguments affect each sub-trend individually.

2. Rosi Braidotti's Posthuman subjectivity has escaped criticism largely because it is not a theory of subjectivity at all, but more of a vitalist theory in line with the panpsychism of Spinoza (Braidotti 2013, 60).

3. A good example of this can be seen in Coole and Frost's New Materialisms: Ontology, Agency, and Politics $(2010,6)$ where theory is described as either materialist/real or constructivist/unreal, as if these are the only two forms in which theory can exist, ignoring all the philosophical, anthropological, archaeological, etc. theory that does not fall into either of these categories.

4. One of the more popular ideas used in recent years to explain the phenomenon of how social processes occur through time is that of 'emergence'. As has been pointed out by John Searle (2016, 403), this notion is simply a 'filler' that has no explanatory power in itself. For example, emergence theory cannot explain why 'brushing teeth' became a social norm, any more than why some societies have not embraced this norm. As a general theory, it fails to account for the historical conditions that allow some norms to arise; furthermore, even when taking those conditions into account, it still fails to identify why some norms arise and others do not.

Artur Ribeiro SFB 1266 - Scales of Transformation Christian-Albrechts-Universität zu Kiel Leibniztraße 3

Kiel 24118 Germany Email:aribeiro@sfb1266.uni-kiel.de

\section{References}

Barrett, J.C., 1988. Fields of discourse: reconstituting a social archaeology. Critique of Anthropology 7(3), 5-16.

Bell, C.M., 1992. Ritual Theory, Ritual Practice. Oxford/ New York: Oxford University Press.

Bennett, J., 2010a. Vibrant Matter: A political ecology of things. Durham/London: Duke University Press.

Bennett, J., 2010b. A vitalist stopover on the way to a New Materialism, in New Materialisms: Ontology, agency, and politics, eds D. Coole, \& S. Frost. Durham/ London: Duke University Press, 47-69.

Bourdieu, P., 1977. Outline of a Theory of Practice. Cambridge/New York: Cambridge University Press.

Braidotti, R., 2013. The Posthuman. Cambridge: Polity Press.

Braidotti, R., 2019. Posthuman Knowledge. Cambridge/ Medford: Polity.

Bremmer, J.N., 1999. The birth of the term 'magic'. Zeitschrift für Papyrologie und Epigraphik 126, 1-12.

Coole, D. \& S. Frost, 2010. Introducing the New Materialisms, in New Materialisms: Ontology, agency, and politics, eds D. Coole, \& S. Frost. Durham/ London: Duke University Press, 1-43.

DeLanda, M., 2006. A New Philosophy of Society: Assemblage theory and social complexity. London: Continuum.

Dennett, D.C., 1991. Consciousness Explained. Boston (MA): Little, Brown.

Descombes, V., 2001. The Mind's Provisions: A critique of cognitivism. Princeton/Oxford: Princeton University Press.

Descombes, V., 2014. The Institutions of Meaning: A defense of anthropological holism. Cambridge/London: Harvard University Press.

Gardner, A. \& E. Cochrane, 2011. Evolutionary and interpretive archaeologies: a dialogue, in Evolutionary and Interpretive Archaeologies, eds E. Cochrane \& A. Gardner. Walnut Creek (CA): Left Coast Press, 11-29.

Garner, B.A., 1999. Black's Law Dictionary (7th edn). Saint Paul (MN): West Group.

Giddens, A., 1984. The Constitution of Society: Outline of the theory of structuration. Cambridge/Oxford: Polity Press.

Hamilakis, Y., 2017. Sensorial assemblages: affect, memory and temporality in assemblage thinking. Cambridge Archaeological Journal 27(1), 169-82.

Harman, G., 2017. Object-oriented Ontology: A new theory of everything. London: Penguin.

Harris, O.J.T., 2014. (Re)assembling communities. Journal of Archaeological Method and Theory 21(1), 76-97.

Harris, O.J.T., 2017. Assemblages and scale in archaeology. Cambridge Archaeological Journal 27(1), 127-39.

Harris, O.J.T., 2018. Assemblage, in The Encyclopedia of Archaeological Sciences, ed. S.L.L. Varela. Hoboken (NJ): Wiley.

Harris, O.J.T. \& C.N. Cipolla, 2017. Archaeological Theory in the New Millennium: Introducing current perspectives. London/New York: Routledge. 
Helms, M.W., 1998. Access to Origins: Affines, ancestors, and aristocrats. Austin (TX): University of Texas Press.

Hinz, M., J. Schirrmacher, J. Kneisel, C. Rinne \& M. Weinelt, 2019. The Chalcolithic-Bronze Age transition in southern Iberia under the influence of the $4.2 \mathrm{kyr}$ event? A correlation of climatological and demographic proxies. Journal of Neolithic Archaeology 21, 1-26.

Hornborg, A., 2019. Nature, Society, and Power in the Anthropocene: Unravelling the money-energy-technology complex. Cambridge/New York: Cambridge University Press.

Jones, A.M., B. Alberti, C. Fowler \& G. Lucas, 2013 Archaeology after interpretation, in Archaeology After Interpretation: Returning materials to archaeological theory, eds. A.M. Jones \& J. Pollard. Walnut Creek (CA): Left Coast Press, 15-35.

Kervégan, J.-F., 2018. The Actual and the Rational: Hegel and objective spirit. Chicago/London: University of Chicago Press.

Kim, J., E. Sosa \& G.S. Rosenkrantz, 2009. A Companion to Metaphysics. Oxford: Wiley-Blackwell.

Knappett, C., 2004. The Affordances of Things: A post-Gibsonian perspective on the relationality of mind and matter. Cambridge: McDonald Institute for Archaeological Research.

Kopytoff, I., 1986. The cultural biography of things: commoditization as a process, in The Social Life of Things, ed. A. Appadurai. Cambridge: Cambridge University Press, 64-91.

Kristiansen, K., 2004. Genes versus agents. A discussion of the widening theoretical gap in archaeology. Archaeological dialogues 11(2), 77-99.

Latour, B., 1993. We Have Never Been Modern. New York/ London: Harvester Wheatsheaf.

Latour, B., 1999. Pandora's Hope: Essays on the reality of science studies. Cambridge/London: Harvard University Press.

Lillios, K.T., 2020. The Archaeology of the Iberian Peninsula: From the Palaeolithic to the Bronze Age. Cambridge/ New York: Cambridge University Press.

Loux, M.J. \& T.M. Crisp, 2017. Metaphysics - A contemporary introduction (4th edn). London/New York: Routledge.

Loux, M.J. \& D.W. Zimmerman, 2003. The Oxford Handbook of Metaphysics. Oxford: Oxford University Press.

Meillassoux, Q., 2008. After Finitude: An essay on the necessity of contingency. London: Continuum.

Mittnik, A., K. Massy, C. Knipper, et al., 2019. Kinship-based social inequality in Bronze Age Europe. Science 366(6466), 731-4.

Olalde, I., S. Mallick, N. Patterson, et al., 2019. The genomic history of the Iberian Peninsula over the past 8000 years. Science 363(6432), 1230-34.

Olsen, B., 2012. After interpretation: remembering archaeology. Current Swedish Archaeology 20, 11-34.

Olsen, B., 2010. In Defense of Things: Archaeology and the ontology of objects. Lanham/Plymouth: Rowman \& Littlefield.

Olsen, B., M. Shanks, T. Webmoor \& C. Witmore, 2012. Archaeology: The discipline of things. Berkeley (CA): University of California Press.
Pétursdóttir, P., 2017. Climate change? Archaeology and Anthropocene. Archaeological Dialogues 24(2), 175-205.

Pippin, R.B., 1989. Hegel's Idealism: The satisfactions of selfconsciousness. Cambridge: Cambridge University Press.

Pippin, R.B., 2005. The Persistence of Subjectivity: On the Kantian aftermath. Cambridge/New York: Cambridge University Press.

Pippin, R.B., 2008. Hegel's Practical Philosophy: Rational agency as ethical life. Cambridge/New York: Cambridge University Press.

Pippin, R.B., 2011. Hegel on Self-consciousness: Desire and death in the phenomenology of spirit. Princeton (NJ): Princeton University Press.

Ribeiro, A., 2019. Archaeology and the new metaphysical dogmas: comments on ontologies and reality. Forum Kritische Archäologie 8, 25-38.

Robb, J.E., 2010. Beyond agency. World Archaeology 42(4), 493-520.

Sahlins, M.D., 1972. Stone Age Economics. London/ New York: Routledge.

Searle, J.R., 1980. Minds, brains, and programs. Behavioral and Brain Sciences 3(3), 417-24.

Searle, J.R., 2016. The limits of emergence: reply to Tony Lawson. Journal for the Theory of Social Behaviour 46(4), 400-412.

Siedentop, L., 2014. Inventing the Individual: The origins of Western liberalism. Cambridge (MA): Belknap Press of Harvard University Press.

Sorell, T., 2005. Descartes Reinvented. Cambridge: Cambridge University Press.

Taylor, C., 1975. Hegel. Cambridge/New York: Cambridge University Press.

Taylor, C., 2015. Hegel and Modern Society. Cambridge: Cambridge University Press.

Turner, S.P., 1994. The Social Theory of Practices: Tradition, tacit knowledge, and presuppositions. Chicago (IL): University of Chicago Press.

Van Inwagen, P., 2014. Metaphysics (4th edn). Boulder (CO): Westview Press.

Versnel, H.S., 1991a. Some reflections on the relationship magic-religion. Numen 38(2), 177-97.

Versnel, H.S., 1991b. Beyond cursing: the appeal to justice in judicial prayers, in Magika Hiera, eds C.A. Faraone \& D. Obbink. Oxford: Oxford University Press, 60-106.

Wagner, R., 1972. Incest and identity: a critique and theory on the subject of exogamy and incest prohibition. Man 7(4), 601-13.

Webmoor, T. \& C. Witmore, 2008. Things are us! A commentary on human/things relations under the banner of a 'social' archaeology. Norwegian Archaeological Review 41(1), 53-70.

Witmore, C.L., 2007. Symmetrical archaeology: excerpts of a manifesto. World Archaeology 39(4), 546-62.

Žižek, S., 2012. Less than Nothing: Hegel and the shadow of dialectical materialism. London/New York: Verso.

Žižek, S., 2014. Absolute Recoil: Towards a new foundation of dialectical materialism. London/New York: Verso. 


\section{Author biography}

Artur Ribeiro (PhD, University of Kiel, 2016) is an archaeologist who has worked primarily in Portugal and Ireland, where he has excavated numerous prehistoric,
Roman and modern archaeological sites. His more recent work focuses on archaeological theory and philosophical stances in archaeology, with a particular emphasis on the relation of historical understanding and archaeological interpretation. 